\title{
EFFECT OF THERMOMECHANICAL TREATMENT ON THE INTERGRANULAR CORROSION OF Al-Mg-Si-Type ALLOY BARS
}

\author{
VPLIV TERMOMEHANSKE PREDELAVE NA INTERKRISTALNO \\ KOROZIJO PALIC IZ ZLITIN Al-Mg-Si
}

\author{
Peter Sláma, Jan Nacházel \\ COMTES FHT a.s., Průmyslová 995, 33441 Dobřany, Czech Republic \\ peter.slama@comtesfht.cz \\ Prejem rokopisa - received: 2015-07-01; sprejem za objavo - accepted for publication: 2015-02-12
}

doi:10.17222/mit.2015.170

\begin{abstract}
Al-Mg-Si-type alloys (6xxx-series alloys) exhibit good mechanical properties, formability, weldability and good corrosion resistance in a variety of environments. They often find use in the automotive industry and other applications. Some alloys, however, particularly those with higher copper levels, show increased susceptibility to intergranular corrosion. Intergranular corrosion (IGC) is typically related to the formation of microgalvanic cells between cathodic, more-noble phases and depleted (precipitate-free) zones along the grain boundaries. It is encountered mainly in $\mathrm{Al}-\mathrm{Mg}$-Si alloys containing $\mathrm{Cu}$, where it is thought to be related to the formation Q-phase precipitates $\left(\mathrm{Al}_{4} \mathrm{Mg}_{8} \mathrm{Si}_{7} \mathrm{Cu}_{2}\right)$ along the grain boundaries. The present paper describes the effects of mechanical working (pressing, drawing and straightening) and artificial ageing on intergranular corrosion in a bar of the 6064 alloy. The resistance to intergranular corrosion was mapped using corrosion tests according to EN ISO 11846 , method $\mathrm{B}$. The corrosion tests showed that with continuing ageing and over-ageing, deep IGC changes into pitting corrosion with a smaller depth of attack. However, the corrosion resistance of the bars is impaired by post-quench mechanical working (drawing and straightening).

Keywords: Al-Mg-Si-Cu alloy, 6064 alloy, extruded bars, thermomechanical treatment, intergranular corrosion, pitting corrosion
\end{abstract}

Zlitine vrste Al-Mg-Si (6xxx-vrsta zlitin) kažejo dobre mehanske lastnosti: preoblikovalnost, varivost in dobro korozijsko odpornost v različnih okoljih. Pogosto se uporabljajo v avtomobilski industriji in tudi v druge namene. Vendar pa nekatere zlitine, posebno tiste z višjo vsebnostjo bakra, kažejo povečano občutljivost na interkristalno korozijo. Interkristalna korozija (IGC) je značilno povezana z nastankom mikrogalvanskih celic med katodno, bolj plemenito fazo in osiromašenim (brez izločkov) področjem, vzdolž meja kristalnih zrn. To se pojavlja predvsem v AlMgSi zlitinah, ki vsebujejo Cu in kjer se predpostavlja, da je to povezano $\mathrm{z}$ nastankom izločkov Q-faze $\left(\mathrm{Al}_{4} \mathrm{Mg}_{8} \mathrm{Si}_{7} \mathrm{Cu}_{2}\right)$, vzdolž meja med zrni. Clanek opisuje vpliv mehanskega preoblikovanja (stiskanje, vlečenje, ravnanje) in vpliv umetnega staranja na interkristalno korozijo palic iz zlitine 6064. Odpornost na interkristalno korozijo je bila preslikana s pomočjo korozijskih preizkusov, skladno s standardom EN ISO 11846, metoda B. Korozijski preizkusi so pokazali da se z nadaljevanjem staranja in prestaranjem globoke interkristalne korozije, spremenijo v jamičasto korozijo, z manjšo globino napada. Vseeno pa je korozijska odpornost palic poslabšana $\mathrm{z}$ mehansko predelavo (vlečenje in ravnanje) po gašenju.

Ključne besede: zlitina Al-Mg-Si-Cu, zlitina 6064, iztiskane palice, termomehanska predelava, interkristalna korozija, jamičasta korozija

\section{INTRODUCTION}

Al-Mg-Si-type alloys (6xxx-series alloys) exhibit good mechanical properties, formability, weldability and good corrosion resistance in a variety environments. They frequently find use in automotive, aviation and other applications. ${ }^{1,2}$ Some of these materials are alloyed with copper to improve their strength. In these alloys, particularly higher-copper alloys, increased susceptibility to intergranular corrosion (IGC) can be observed, most notably in the unaged condition and less often in the $\mathrm{T} 6$ temper condition. The effects of $\mathrm{Cu}$ as well as the opportunities for enhancing the resistance to intergranular corrosion have received considerable attention in a number of studies. ${ }^{3-11}$ Intergranular corrosion (IGC) is typically related to the formation of microgalvanic cells between the cathodic more-noble phases and the depleted (precipitate-free) zones along the grain boundaries. It is encountered mainly in AlMgSi alloys that contain $\mathrm{Cu}$, where it is thought to be linked to the formation of cathodic Q-phase $\left(\mathrm{Al}_{4} \mathrm{Mg}_{8} \mathrm{Si}_{7} \mathrm{Cu}_{2}\right)$ along the grain boundaries. The occurrence of phases along the grain boundaries was observed using scanning-transmission electron microscopy (STEM).

The impact of $\mathrm{Cu}$ additions and heat treatment on IGC was described in several papers. ${ }^{3-6}$ The alloys contained $0.5-0.6 \% \mathrm{Mg}, 0.6-0.8 \% \mathrm{Si}, 0.2 \% \mathrm{Fe}, 0.2 \%$ $\mathrm{Mn}$ and $\mathrm{Cu}$ at 0.02 through $0.7 \%$ of mass fractions. The occurrence of IGC was monitored in $2.5 \mathrm{~mm} \times 78 \mathrm{~mm}$ extruded flat bars. The effects of the cooling rate from the extrusion temperature were studied ${ }^{3}$, as were the effects of artificial ageing. ${ }^{4,5}$ Corrosion tests were carried out according to EN ISO 11846, method B. Corrosion was only monitored on the surface of the extruded parts. EN ISO 11846 specifies that the corrosion is monitored on the long side of the specimen. In an alloy with a $\mathrm{Cu}$ level of $0.02 \%$, no IGC was found. In an alloy with 


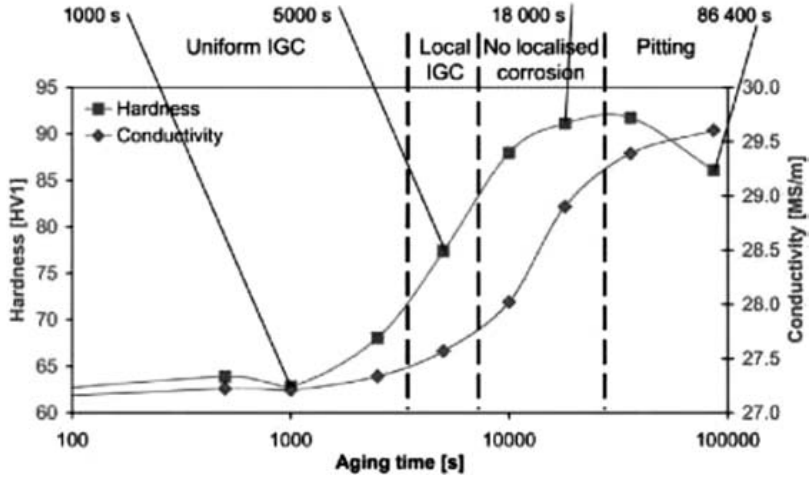

Figure 1: The dominant corrosion types in a material aged at $185^{\circ} \mathrm{C}$, according to 5

Slika 1: Prevladujoče oblike korozije v materialu, staranem na $185{ }^{\circ} \mathrm{C}$ po viru ${ }^{5}$

$0.2 \% \mathrm{Cu}$, IGC occurred depending on the artificial ageing time, and changed into pitting corrosion. These findings suggest that between the occurrence of IGC and pitting corrosion, there is a region in which no IGC occurs (Figure 1)

Hence, over-ageing (by increasing either temperature or time) permits a transition from a region with IGC to a region with suppressed IGC.

The AA6056 material for the aviation industry is used in overaged condition. It is supplied in the T78 state with an enhanced resistance to IGC. According to ${ }^{6,7}$, the T78 temper is achieved by two-stage ageing: $175^{\circ} \mathrm{C} / 6 \mathrm{~h}$ $+210^{\circ} \mathrm{C} / 5 \mathrm{~h}$.

Two-stage ageing was explored by the authors of the study. ${ }^{11}$ The alloy had a nominal composition of $1.0 \%$ $\mathrm{Mg}, 1.2 \% \mathrm{Si}, 0.3 \% \mathrm{Cu}, 0.6 \% \mathrm{Mn}, 0.12 \% \mathrm{Cr}, 0.12 \%$ $\mathrm{Fe}$ and a balance of $\mathrm{Al}$. An ageing schedule specified as $180{ }^{\circ} \mathrm{C} / 2 \mathrm{~h}+160{ }^{\circ} \mathrm{C} / 120 \mathrm{~h}$ led to better results than $175^{\circ} \mathrm{C} / 6 \mathrm{~h}+210^{\circ} \mathrm{C} / 5 \mathrm{~h}$. However, this work was carried out using specimens of rolled sheet with a 2-mm thickness, where the corrosion attack was monitored on the sheet surface and not on its cross-section.

Thermomechanical treatment generally has a great influence on the corrosion in other types of aluminium alloys. ${ }^{12}$ In this research the effect of the thermomechanical treatment (extrusion, drawing and ageing) on the intergranular corrosion in bars from EN AW-6064A (AlMg1SiBi) machineable alloy was studied. AlMgSi-type machinable alloys are used in the automotive industry. Their improved machinability is imparted by alloying with $\mathrm{Pb}$ (6012 alloy) or with $\mathrm{Bi}+\mathrm{Pb}$ (6262 and 6064 alloys). These alloys have higher alloy levels and contain more phases than the alloys studied in ${ }^{3-11}$. These phases include $\mathrm{Bi}$ and $\mathrm{Pb}$ cathodic particles.

\section{EXPERIMENTAL PART}

The chemical composition of the EN AW-6064A bars is shown in Table 1. The bars of $17 \mathrm{~mm}$ diameter were made by an industrial hot-extrusion process using a multiple-hole die. The process temperature was $540-546{ }^{\circ} \mathrm{C}$.
Right after extrusion, the bars were water-wave cooled (T1 condition). The quenched bars were then drawn to the final diameter of $15 \mathrm{~mm}$ at $22 \%$ reduction and straightened in a Schumag straightening machine (T2 temper). The final operation was artificial ageing to T8. Bars in conditions corresponding to each process step were gathered for testing. The samples are listed in Table 2.

The bars that did not undergo ageing (HA1, HB2 and $\mathrm{HF})$ were used in artificial ageing trials: single-stage and two-stage ageing to the under-aged, peak-aged and over-aged condition. The artificial ageing schedules are presented in Table 3 .

Table 1: Chemical composition of the alloy 6064A, in mass fractions $(w / \%)$

Tabela 1: Kemijska sestava zlitine 6064A, v masnih deležih ( $w / \%)$

\begin{tabular}{|c|c|c|c|c|c|c|c|c|}
\hline Sample & $\mathrm{Si}$ & $\mathrm{Fe}$ & $\mathrm{Cu}$ & $\mathrm{Mn}$ & $\mathrm{Mg}$ & $\mathrm{Cr}$ & $\mathrm{Pb}$ & $\mathrm{Bi}$ \\
\hline $\mathrm{H}$ & 0.60 & 0.23 & 0.27 & 0.04 & 1.03 & 0.05 & 0.28 & 0.49 \\
\hline
\end{tabular}

Table 2: Samples description

Tabela 2: Opis vzorcev

\begin{tabular}{|c|c|c|l|}
\hline Sample & Diameter & Temper & $\begin{array}{l}\text { Description of thermomechanical } \\
\text { processing }\end{array}$ \\
\hline HA1 & $17 \mathrm{~mm}$ & $\mathrm{~T} 1$ & Extruding, quenching \\
\hline HB2 & $15 \mathrm{~mm}$ & $\mathrm{~T} 2$ & Extruding, quenching, drawing \\
\hline HF & $15 \mathrm{~mm}$ & $\mathrm{~T} 2$ & $\begin{array}{l}\text { Extruding, quenching, drawing, } \\
\text { straightening }\end{array}$ \\
\hline HC & $15 \mathrm{~mm}$ & $\mathrm{~T} 8$ & $\begin{array}{l}\text { Extruding, quenching, drawing, } \\
\text { straightening, ageing }\end{array}$ \\
\hline
\end{tabular}

Table 3: Heat treatment HT (artificial ageing) for samples HA1, HB2, $\mathrm{HF}$

Tabela 3: Toplotna obdelava (umetno staranje) vzorcev HA1, HB2, $\mathrm{HF}$

\begin{tabular}{|c|c|c|c|c|c|}
\hline HT & One-stage & HT-A & Two-stage A & HT-B & Two-stage B \\
\hline 1 & $160^{\circ} \mathrm{C} / 4 \mathrm{~h}$ & $1 \mathrm{~A}$ & $\begin{array}{c}160^{\circ} \mathrm{C} / 4 \mathrm{~h}+ \\
220^{\circ} \mathrm{C} / 4 \mathrm{~h}\end{array}$ & $1 \mathrm{~B}$ & $\begin{array}{c}160^{\circ} \mathrm{C} / 4 \mathrm{~h}+ \\
205^{\circ} \mathrm{C} / 4 \mathrm{~h}\end{array}$ \\
\hline 2 & $160^{\circ} \mathrm{C} / 8 \mathrm{~h}$ & $2 \mathrm{~A}$ & $\begin{array}{c}160^{\circ} \mathrm{C} / 8 \mathrm{~h}+ \\
220^{\circ} \mathrm{C} / 4 \mathrm{~h}\end{array}$ & $2 \mathrm{~B}$ & $\begin{array}{c}160{ }^{\circ} \mathrm{C} / 8 \mathrm{~h}+ \\
205^{\circ} \mathrm{C} / 4 \mathrm{~h}\end{array}$ \\
\hline 3 & $180^{\circ} \mathrm{C} / 4 \mathrm{~h}$ & $3 \mathrm{~A}$ & $\begin{array}{c}180^{\circ} \mathrm{C} / 4 \mathrm{~h}+ \\
220^{\circ} \mathrm{C} / 4 \mathrm{~h}\end{array}$ & $3 \mathrm{~B}$ & $\begin{array}{c}180^{\circ} \mathrm{C} / 4 \mathrm{~h}+ \\
205^{\circ} \mathrm{C} / 4 \mathrm{~h}\end{array}$ \\
\hline 4 & $180^{\circ} \mathrm{C} / 8 \mathrm{~h}$ & & & & \\
\hline
\end{tabular}

The progress of ageing was monitored by a HV5 hardness measurement using a DURASCAN 50 hardness tester. Tests of resistance to intergranular corrosion were conducted in accordance the EN ISO 11846 standard, method B. ${ }^{13}$ For these tests, specimens of $2 \mathrm{~cm}$ in length were made from the bars. Their cut surfaces were ground with P-1200 grinding papers. The original surface of the bar was not altered. Before testing, the specimens were degreased in acetone. In accordance with the standard requirements, they were etched with $5 \% \mathrm{NaOH}$ solution at $55{ }^{\circ} \mathrm{C}$ for $2 \mathrm{~min}$. After a water rinse, they were placed in concentrated nitric acid for cleaning. The test itself involved submerging in a test solution for $24 \mathrm{~h}$ at room temperature. The solution was $30 \mathrm{~g} \mathrm{NaCl} / \mathrm{L}$ solution + $10 \mathrm{~mL}$ concentrated hydrochloric acid. 
Following the test, the specimens were rinsed with water. Metallographic sections were prepared on longitudinal cross-sections through the specimens. The corrosion attacks on the bar surface as well as on the transverse cut surface were examined. The maximum corrosion depth was determined and documented using light microscopy. The surfaces of the specimens after corrosion testing were examined in a JEOL JSM 6380 scanning electron microscope.

\section{RESULTS}

\subsection{Initial microstructures}

The microstructure of T8-temper HC bars upon drawing, straightening and ageing is shown in Figure 2a. A micrograph of the phases is in Figure $\mathbf{2 b}$. The microstructure is fully recrystallized. The grains in the surface layer are relatively fine, with a size of $70 \mu \mathrm{m}$. In the centre, the grains are coarser, of the order of several hundred $\mu \mathrm{m}$. Different grain sizes in the surface and in the interior are a typical occurrence in extruded bars from Al alloys. Typically, the surface layer contains coarse grains and the interior remains unrecrystallized., ${ }^{1,2}$
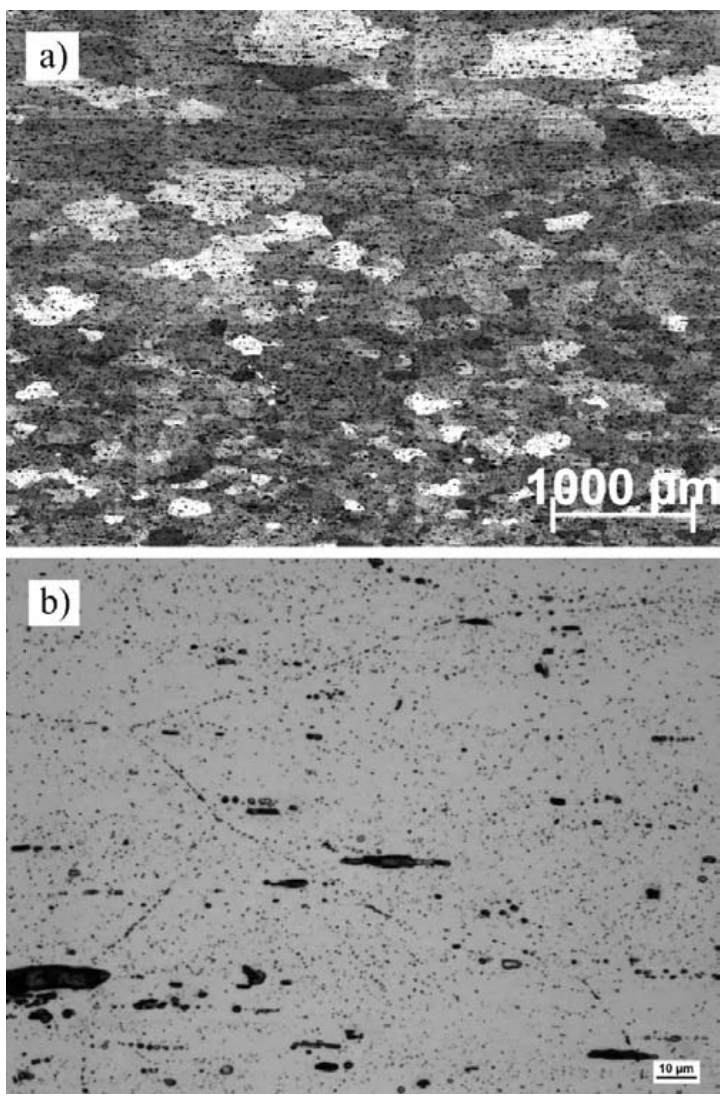

Figure 2: Micrographs of grains and phases in HC samples upon drawing and ageing: a) electrolytically etched with Barker's reagent, polarised light, b) etched with Dix-Keller's reagent

Slika 2: Posnetka zrn in faz v HC vzorcu, po vlečenju in staranju: a) elektrolitsko jedkano z Baker jedkalom, polarizirana svetloba, b) jedkano z Dix-Keller jedkalom
The phases in the microstructure are banded and aligned in the extrusion/drawing direction. Large elongated particles consist of $\mathrm{Bi}$ or $\mathrm{Bi}+\mathrm{Pb}$. The small ones are alpha- $\mathrm{Al}_{15}(\mathrm{Fe}, \mathrm{Mn}, \mathrm{Cu}, \mathrm{Cr})_{3} \mathrm{Si}_{2}$ particles. Other small particles are $\mathrm{Mg}_{2} \mathrm{Si}$ particles. The $\mathrm{Bi}, \mathrm{Pb}$ and alpha$\mathrm{Al}_{15}(\mathrm{Fe}, \mathrm{Mn}, \mathrm{Cu}, \mathrm{Cr})_{3} \mathrm{Si}_{2}$ particles are more noble, cathodic. The $\mathrm{Mg}_{2} \mathrm{Si}$ particles are anodic. With cathodic particles, the matrix of the aluminium solid solution is etched away preferentially when placed in a corrosion environment. With anodic particles, it is the particles that are attacked. The microstructure may also contain cathodic Q-phase particles $\left(\mathrm{Al}_{4} \mathrm{Mg}_{8} \mathrm{Si}_{7} \mathrm{Cu}_{2}\right)$. Figure 2b also shows minute particles along grain boundaries. EDS analysis revealed that they contain higher amounts of copper, which suggests that they are Q-phase particles.

\subsection{Corrosion tests}

Specimens to be tested according to EN ISO 11846 , method B, are to be alkaline pre-etched with 5-10\% $\mathrm{NaOH}$ solution. With this etch, the $\mathrm{Al}$ matrix and anodic phases are attacked. The etched surface of a specimen is shown in Figure 3. The large pits are the result of the Al matrix being etched away from around the $\mathrm{Bi}, \mathrm{Pb}$ and alpha- $\mathrm{Al}_{15}(\mathrm{Fe}, \mathrm{Mn}, \mathrm{Cu}, \mathrm{Cr})_{3} \mathrm{Si}_{2}$ cathodic phases. The small pits are the locations of $\mathrm{Mg}_{2} \mathrm{Si}$ anodic particles that were

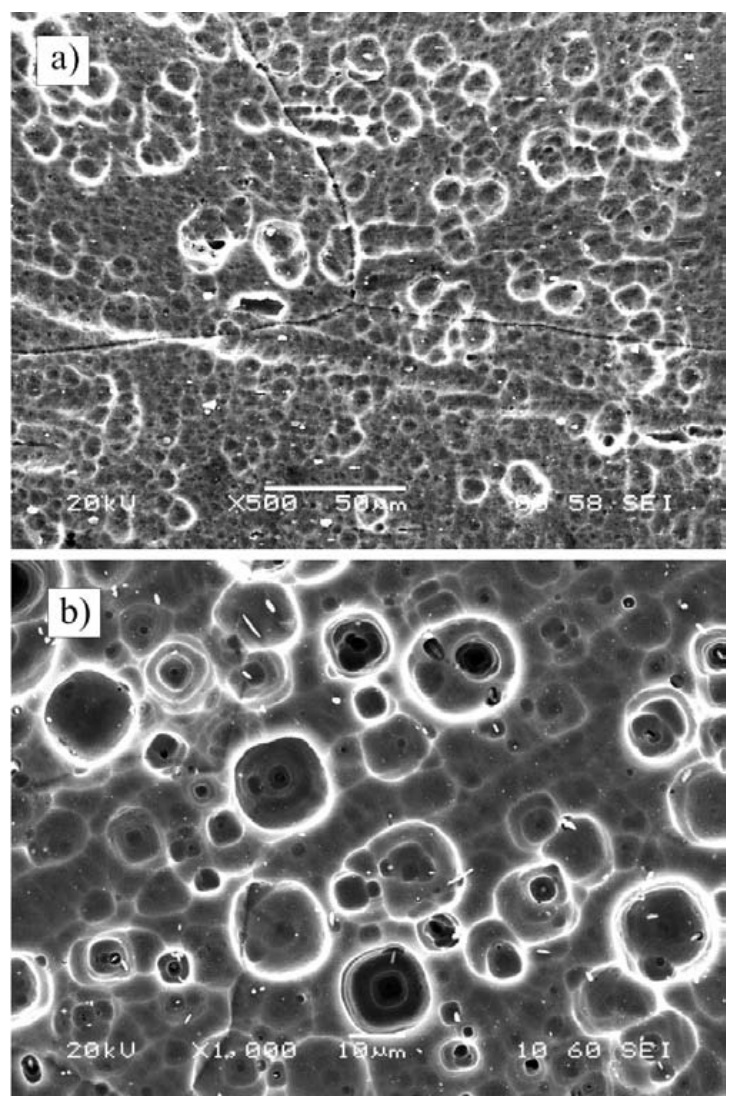

Figure 3: SEM micrographs of the surface of HC sample upon etching with $\mathrm{NaOH}$ : a) sample surface, b) transverse cut surface

Slika 3: SEM-posnetka površine vzorca HC, po jedkanju z $\mathrm{NaOH}$ : a) površina vzorca, b) prečni prerez vzorca 
etched away. The grain boundaries were slightly attacked.

In order to evaluate the corrosion, the specimens were cut longitudinally after the test. On the cross-section, the type and depth of the corrosion on the bar's surface and on its transverse cut surface were examined.

\subsubsection{Corrosion tests of materials in initial condition}

The initial condition evaluation was carried out on HF samples supplied in the T2 (non-aged) condition and on the HC samples supplied in the T8 (peak-aged) condition. The HC bars were drawn and aged during the $24 \mathrm{~h}$ following quenching. The surface corrosion is shown in Figure 4. Its evaluation is detailed in Table 4.

Table 4: Evaluation of corrosion and hardness of initial samples in T2 and $\mathrm{T} 8$ condition

Tabela 4: Ocena korozije in trdota začetnih vzorcev po T2 in T8 obdelavi

\begin{tabular}{|c|c|c|c|c|c|}
\hline Sample & Temper & HV5 & Place & $\begin{array}{c}\text { Corrosion } \\
\text { depth }(\mu \mathrm{m})\end{array}$ & Corrosion type \\
\hline HF & T2 & 108 & Surface & 420.5 & IGC + pitting \\
\cline { 4 - 6 } & & $\begin{array}{c}\text { Transverse } \\
\text { cut }\end{array}$ & 493.2 & IGC + pitting \\
\hline HC & T8 & 124.3 & Surface & 217.8 & $\begin{array}{c}\text { Pitting, } \\
\text { transgranular }\end{array}$ \\
\cline { 4 - 6 } & & $\begin{array}{c}\text { Transverse } \\
\text { cut }\end{array}$ & 607.7 & Pitting \\
\hline
\end{tabular}

The surface of the non-aged HF sample shows extensive intergranular corrosion (IGC) with a depth of more than $420 \mu \mathrm{m}$. In the artificially-aged HC sample (T8 peak-aged temper), the corrosion changed into the pitting type, which spreads perpendicularly to the surface to a depth of more than $200 \mu \mathrm{m}$. The corrosion type corresponds to transgranular corrosion. On the cross-section through the HF specimen, IGC with a
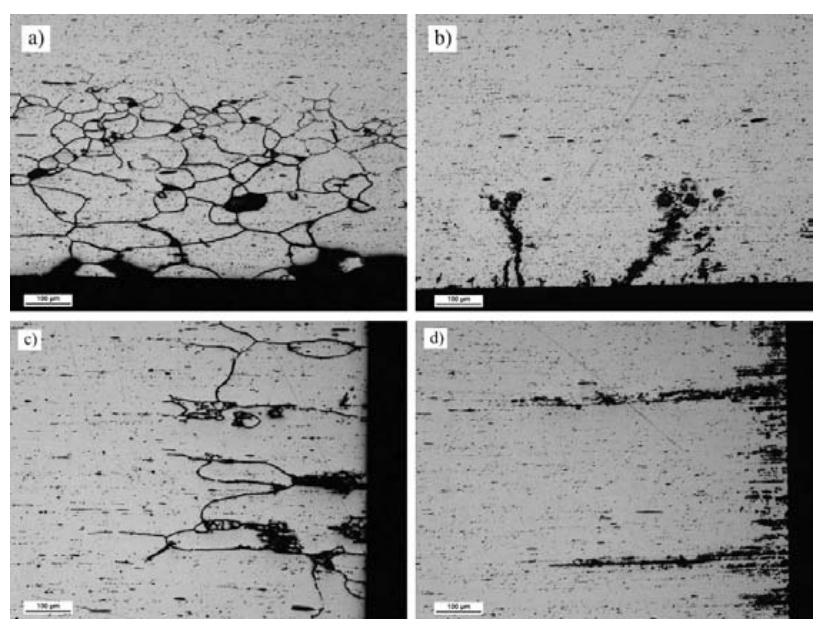

Figure 4: Corrosion attack in as-received bars: a) HF surface - temper T2, non-aged, b) HC surface - temper T8, peak-aged, c) HF transverse cut surface, d) HC transverse cut surface

Slika 4: Korozija na dobavljenih palicah: a) HF površina - žarjenje T2, nestarano, b) HC površina - žarjenje T8, starano, c) HF prečni presek, d) HC prečni presek depth of approximatelz $500 \mu \mathrm{m}$ was found as well. The corrosion on the transverse cut surface of the HC sample is very extensive too. It is, however, pitting-type corrosion, which reached a depth of up to $600 \mu \mathrm{m}$. It follows the bands of coarse cathodic $\mathrm{Bi}, \mathrm{Pb}$ and alpha- $\mathrm{Al}_{15}(\mathrm{Fe}, \mathrm{Mn}, \mathrm{Cu}, \mathrm{Cr})_{3} \mathrm{Si}_{2}$ particles (Figure 4d). Table 4 lists HV5 hardness values. The HF sample in the T2 state exhibits $108 \mathrm{HV} 5$. Age-hardening to T8 increased the hardness to $124 \mathrm{HV} 5$.

\subsubsection{Corrosion tests after experimental heat treatment (artificial ageing)}

Using these tests, the impact of various artificial ageing schedules (under-ageing, over-ageing) on the corrosion in bars in various conditions was monitored:

- Sample HA1 - after extruding and quenching;

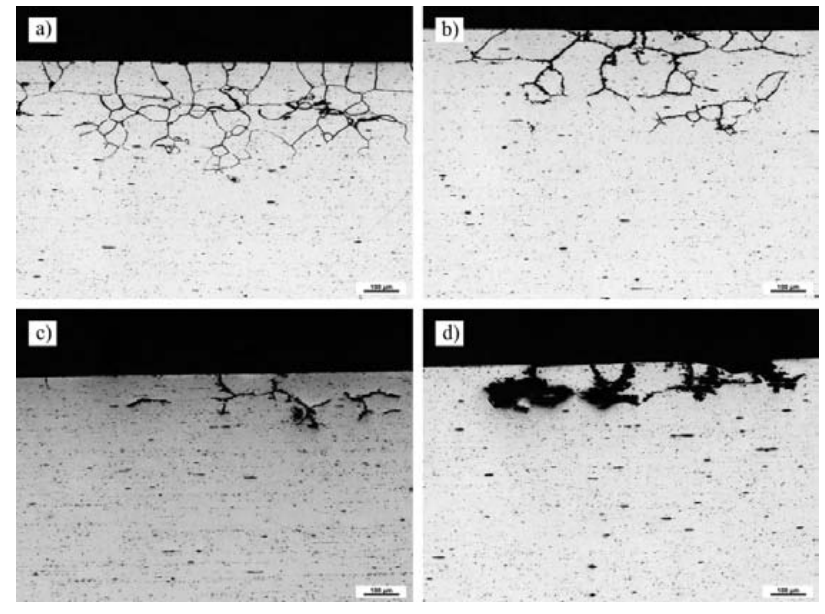

Figure 5: Corrosion on the HA1 bar surface upon ageing: a) $160{ }^{\circ} \mathrm{C} / 8$ h under-aged, b) $180^{\circ} \mathrm{C} / 8 \mathrm{~h}$, c) $160{ }^{\circ} \mathrm{C} / 4 \mathrm{~h}+205^{\circ} \mathrm{C} / 4 \mathrm{~h}$, d) $160{ }^{\circ} \mathrm{C} / 4 \mathrm{~h}$ $+220{ }^{\circ} \mathrm{C} / 4 \mathrm{~h}$ overaged

Slika 5: Korozija na površini HA1 palice, po staranju: a) $160^{\circ} \mathrm{C} / 8 \mathrm{~h}$, podstarano, b) $\left.180{ }^{\circ} \mathrm{C} / 8 \mathrm{~h}, \mathrm{c}\right) 160{ }^{\circ} \mathrm{C} / 4 \mathrm{~h}-205^{\circ} \mathrm{C} / 4 \mathrm{~h}$, d) $160{ }^{\circ} \mathrm{C} / 4 \mathrm{~h}+$ $220^{\circ} \mathrm{C} / 4 \mathrm{~h}$, prestarano
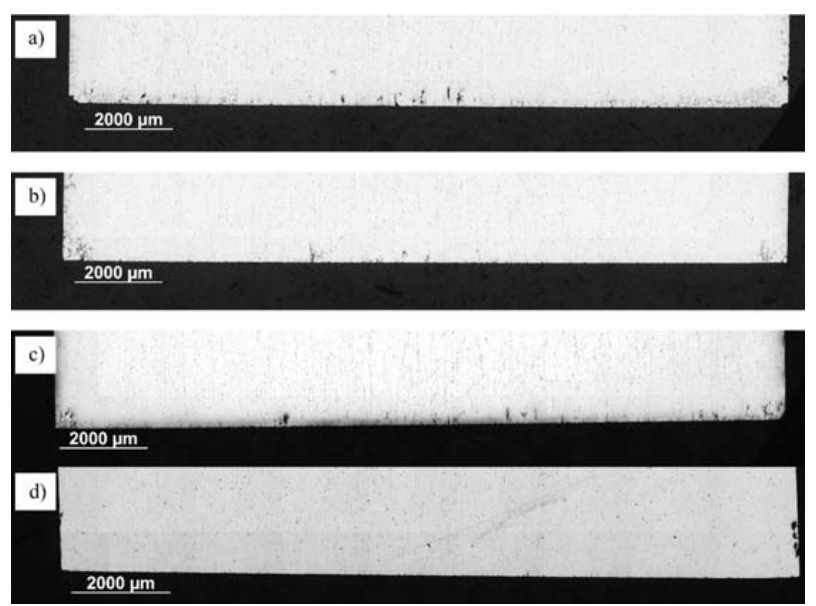

Figure 6: Corrosion on the HA1 transverse cut surface upon ageing: a) $160{ }^{\circ} \mathrm{C} / 8 \mathrm{~h}$ under-aged, b) $180{ }^{\circ} \mathrm{C} / 8 \mathrm{~h}$, c) $160{ }^{\circ} \mathrm{C} / 4 \mathrm{~h}+205^{\circ} \mathrm{C} / 4 \mathrm{~h}$, d) $160{ }^{\circ} \mathrm{C} / 4 \mathrm{~h}+220^{\circ} \mathrm{C} / 4 \mathrm{~h}$ overaged

Slika 6: Korozija na prečnem prerezu HA1 po staranju: a) $160{ }^{\circ} \mathrm{C} / 8 \mathrm{~h}$ podstarano, b) $180{ }^{\circ} \mathrm{C} / 8 \mathrm{~h}$, c) $160{ }^{\circ} \mathrm{C} / 4 \mathrm{~h}+205^{\circ} \mathrm{C} / 4 \mathrm{~h}$, d) $160{ }^{\circ} \mathrm{C} / 4 \mathrm{~h}+$ $220^{\circ} \mathrm{C} / 4 \mathrm{~h}$ prestarano 
- Sample HB2 - after extruding, quenching and drawing;

- Sample HF - after extruding, quenching, drawing and straightening

- Corrosion tests of specimens of HA1 extruded bars

The surface corrosion of selected specimens in variously aged conditions is illustrated in Figure 5. The corrosion of the transverse cut surface is shown in Figure 6. Table 5 contains the results of the corrosion evaluation and the HV5 hardness levels, which indicate the progress of ageing. In specimens in the under-aged condition, the most extensive surface corrosion was found, involving continuous IGC with a maximum depth of more than $300 \mu \mathrm{m}$. In the peak-aged condition, the depth of attack decreased and IGC ceased to be continuous. In the over-aged condition, only sporadic pitting corrosion can be observed with a depth of about $120 \mu \mathrm{m}$.

Table 5: Evaluation of corrosion and hardness of samples HA1 Tabela 5: Ocena korozije in trdota vzorcev HA1

\begin{tabular}{|c|c|c|c|c|}
\hline $\begin{array}{l}\text { Sample } \\
\text { HV5 }\end{array}$ & US & Place & $\begin{array}{l}\text { Corrosion } \\
\text { depth }(\mu \mathrm{m})\end{array}$ & Corrosion type \\
\hline \multirow{2}{*}{$\begin{array}{l}\text { HA } 1-2 \\
92.5\end{array}$} & $160^{\circ} \mathrm{C} / 8 \mathrm{~h}$ & Surface & 309.3 & $\begin{array}{c}\text { IGC + pitting } \\
\text { sporadic }\end{array}$ \\
\hline & Under-ageing & $\begin{array}{c}\text { Transverse } \\
\text { cut }\end{array}$ & 421.1 & $\begin{array}{l}\text { IGC near-edge } \\
\quad+\text { pitting }\end{array}$ \\
\hline \multirow{2}{*}{$\begin{array}{c}\text { HA } 1-4 \\
113.7\end{array}$} & $180^{\circ} \mathrm{C} / 8 \mathrm{~h}$ & Surface & 296.4 & IGC $50 \%$ \\
\hline & peak ageing & $\begin{array}{c}\text { Transverse } \\
\text { cut }\end{array}$ & 460.8 & $\begin{array}{l}\text { IGC near-edge } \\
\quad+\text { pitting }\end{array}$ \\
\hline \multirow{2}{*}{$\begin{array}{c}\text { HA1-1B } \\
114.7\end{array}$} & $\begin{array}{c}160{ }^{\circ} \mathrm{C} / 4 \mathrm{~h}+ \\
205^{\circ} \mathrm{C} / 4 \mathrm{~h}\end{array}$ & Surface & 158.9 & $\begin{array}{c}\text { IGC + pitting } \\
\text { sporadic }\end{array}$ \\
\hline & peak ageing & $\begin{array}{c}\text { Transverse } \\
\text { cut }\end{array}$ & 381.5 & IGC + pitting \\
\hline \multirow{2}{*}{$\begin{array}{c}\text { HA } 1-1 \mathrm{~A} \\
109.3\end{array}$} & $\begin{array}{c}160{ }^{\circ} \mathrm{C} / 4 \mathrm{~h}+ \\
220^{\circ} \mathrm{C} / 4 \mathrm{~h} \\
\end{array}$ & Surface & 120.4 & $\begin{array}{l}\text { Pitting } \\
\text { sporadic }\end{array}$ \\
\hline & Over-ageing & $\begin{array}{c}\text { Transverse } \\
\text { cut }\end{array}$ & 93.4 & $\begin{array}{l}\text { Pitting } \\
\text { sporadic }\end{array}$ \\
\hline
\end{tabular}
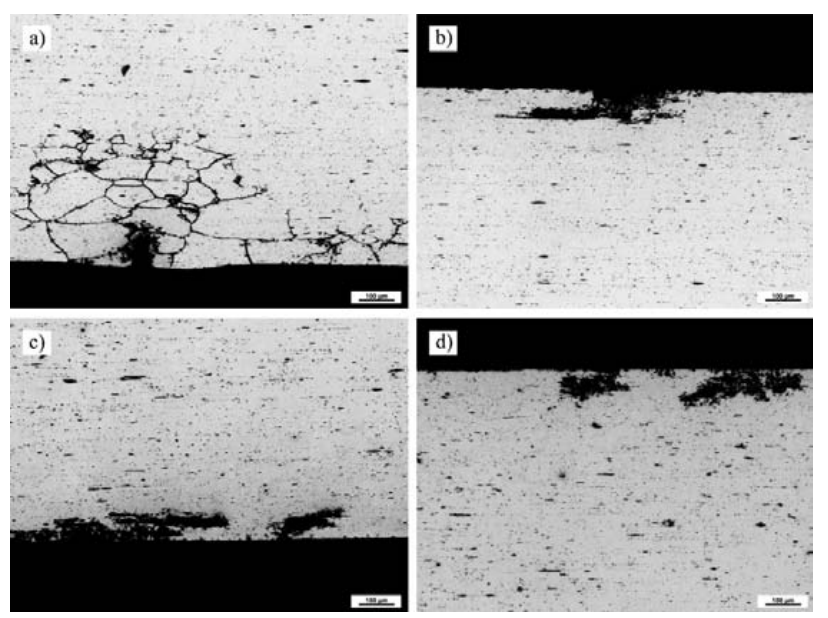

Figure 7: Corrosion on the $\mathrm{HB} 2$ transverse cut surface upon ageing: a) $180{ }^{\circ} \mathrm{C} / 4 \mathrm{~h}$ under-aged, b) $180{ }^{\circ} \mathrm{C} / 8 \mathrm{~h}$, c) $180{ }^{\circ} \mathrm{C} / 4 \mathrm{~h}+205^{\circ} \mathrm{C} / 4 \mathrm{~h}$, d) $180{ }^{\circ} \mathrm{C} / 4 \mathrm{~h}+220^{\circ} \mathrm{C} / 4 \mathrm{~h}$ overaged

Slika 7: Korozija na prečnem prerezu HB2 po staranju: a) $180{ }^{\circ} \mathrm{C} / 4 \mathrm{~h}$ podstarano, b) $180{ }^{\circ} \mathrm{C} / 8 \mathrm{~h}$, c) $180{ }^{\circ} \mathrm{C} / 4 \mathrm{~h}+205^{\circ} \mathrm{C} / 4 \mathrm{~h}$, d) $180{ }^{\circ} \mathrm{C} / 4 \mathrm{~h}+$ $220{ }^{\circ} \mathrm{C} / 4 \mathrm{~h}$ prestarano
The same type of corrosion was found on the transverse cut surface. However, the corrosion depth was larger there: more than $400 \mu \mathrm{m}$. The only exception was the over-aged sample where the depth was less than $100 \mu \mathrm{m}$.

\subsubsection{Corrosion tests of specimens of HB2 drawn bars}

The surface corrosion of selected specimens in variously aged conditions is illustrated in Figure 7. The corrosion of the transverse cut surface is shown in Figure 8. Results of the evaluation of corrosion are given in Table 6.

Table 6: Evaluation of corrosion and hardness of samples HB2 Tabela 6: Ocena korozije in trdota vzorcev HB2

\begin{tabular}{|c|c|c|c|c|}
\hline $\begin{array}{l}\text { Sample } \\
\text { HV5 }\end{array}$ & US & Place & $\begin{array}{c}\text { Corrosion } \\
\text { depth } \\
(\mu \mathrm{m})\end{array}$ & Corrosion type \\
\hline \multirow{2}{*}{$\begin{array}{c}\mathrm{HB} 2-3 \\
120\end{array}$} & $180^{\circ} \mathrm{C} / 4 \mathrm{~h}$ & Surface & 382.5 & $\begin{array}{c}\text { IGC } 60 \%+ \\
\text { pitting sporadic }\end{array}$ \\
\hline & Under-ageing & $\begin{array}{c}\text { Transverse } \\
\text { cut }\end{array}$ & 528.4 & IGC, near-edge \\
\hline \multirow{2}{*}{$\begin{array}{c}\text { HB2-4 } \\
120.7\end{array}$} & $180^{\circ} \mathrm{C} / 8 \mathrm{~h}$ & Surface & 123.6 & Pitting, sporadic \\
\hline & peak ageing & $\begin{array}{c}\text { Transverse } \\
\text { cut }\end{array}$ & 755.6 & \begin{tabular}{|c|} 
Pitting, \\
near-edge
\end{tabular} \\
\hline \multirow{2}{*}{$\begin{array}{c}\mathrm{HB} 2-3 \mathrm{~B} \\
123.3\end{array}$} & $\begin{array}{c}180{ }^{\circ} \mathrm{C} / 4 \mathrm{~h}+ \\
205^{\circ} \mathrm{C} / 4 \mathrm{~h} \\
\end{array}$ & Surface & 81.8 & Pitting \\
\hline & peak ageing & $\begin{array}{c}\text { Transverse } \\
\text { cut }\end{array}$ & 742.6 & Pitting \\
\hline \multirow{2}{*}{$\begin{array}{c}\mathrm{HB} 2-3 \mathrm{~A} \\
106.7\end{array}$} & $\begin{array}{c}180^{\circ} \mathrm{C} / 4 \mathrm{~h}+ \\
220^{\circ} \mathrm{C} / 4 \mathrm{~h} \\
\end{array}$ & Surface & 88.3 & Pitting \\
\hline & Over-ageing & $\begin{array}{c}\text { Transverse } \\
\text { cut }\end{array}$ & 678.1 & $\begin{array}{l}\text { Pitting, } \\
\text { near-edge }\end{array}$ \\
\hline
\end{tabular}

In HB2 drawn bars, IGC was found only in the under-aged condition (Figure 7a). This intergranular
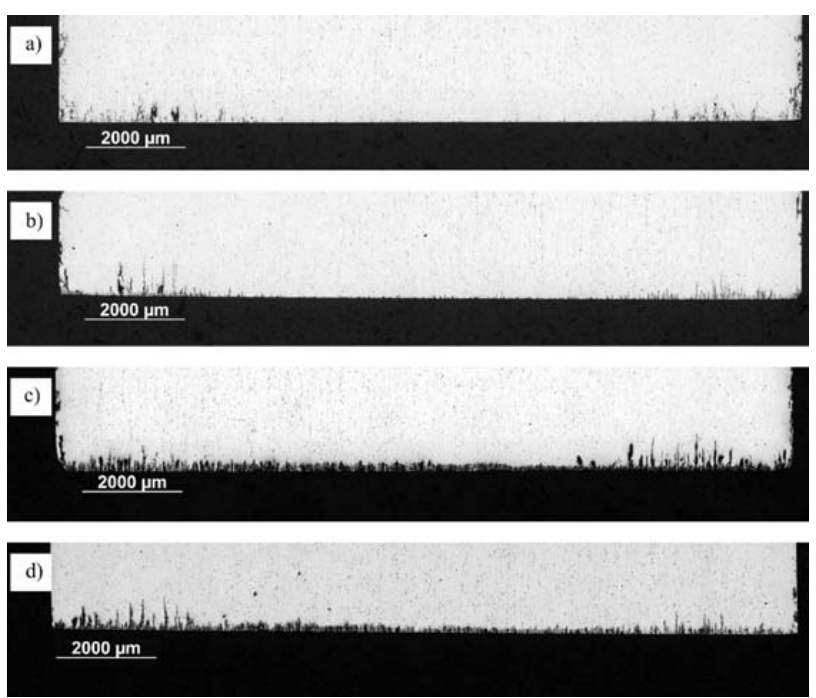

Figure 8: Corrosion on the $\mathrm{HB} 2$ transverse cut surface upon ageing: a) $180{ }^{\circ} \mathrm{C} / 4 \mathrm{~h}$ under-aged, b) $180{ }^{\circ} \mathrm{C} / 8 \mathrm{~h}$, c) $180{ }^{\circ} \mathrm{C} / 4 \mathrm{~h}+205^{\circ} \mathrm{C} / 4 \mathrm{~h}$, d) $180{ }^{\circ} \mathrm{C} / 4 \mathrm{~h}+220^{\circ} \mathrm{C} / 4 \mathrm{~h}$ overaged

Slika 8: Korozija na prečnem prerezu HB2 po staranju: a) $180{ }^{\circ} \mathrm{C} / 4 \mathrm{~h}$ podstarano, b) $180{ }^{\circ} \mathrm{C} / 8 \mathrm{~h}$, c) $180{ }^{\circ} \mathrm{C} / 4 \mathrm{~h}+205^{\circ} \mathrm{C} / 4 \mathrm{~h}$, d) $180{ }^{\circ} \mathrm{C} / 4 \mathrm{~h}+$ $220^{\circ} \mathrm{C} / 4 \mathrm{~h}$ prestarano 

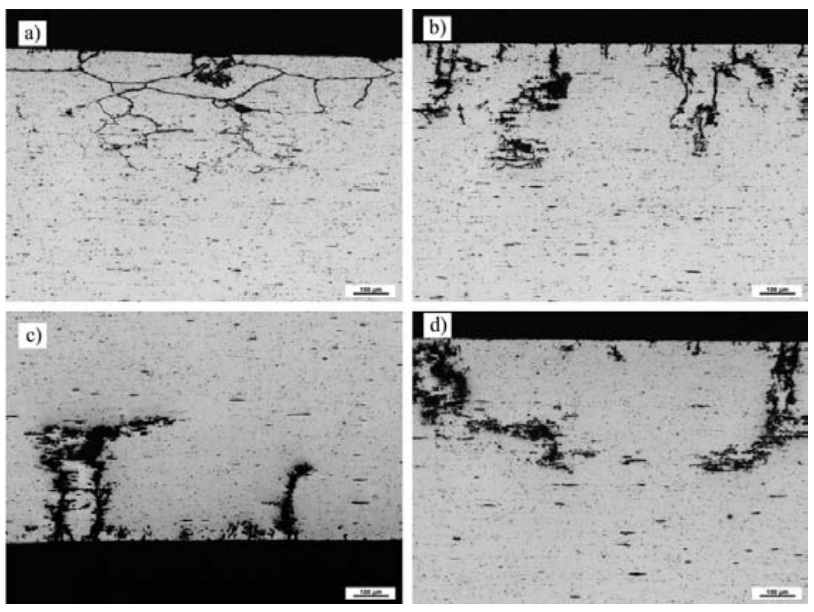

Figure 9: Corrosion on the $\mathrm{HF}$ bar surface upon ageing: a) $180^{\circ} \mathrm{C} / 4 \mathrm{~h}$ under-aged, b) $180{ }^{\circ} \mathrm{C} / 8 \mathrm{~h}$, c) $180{ }^{\circ} \mathrm{C} / 4 \mathrm{~h}+205^{\circ} \mathrm{C} / 4 \mathrm{~h}$, d) $180{ }^{\circ} \mathrm{C} / 4 \mathrm{~h}$ $+220^{\circ} \mathrm{C} / 4 \mathrm{~h}$ overaged

Slika 9: Korozija na površini $\mathrm{HF}$ palice, po staranju: a) $180{ }^{\circ} \mathrm{C} / 4 \mathrm{~h}$ podstarano, b) $\left.180{ }^{\circ} \mathrm{C} / 8 \mathrm{~h}, \mathrm{c}\right) 180{ }^{\circ} \mathrm{C} / 4 \mathrm{~h}+205^{\circ} \mathrm{C} / 4 \mathrm{~h}$, d) $180{ }^{\circ} \mathrm{C} / 4 \mathrm{~h}+$ $220^{\circ} \mathrm{C} / 4 \mathrm{~h}$ prestarano

corrosion is not continuous. On the surface of the bar, the corrosion depth is approx. $400 \mu \mathrm{m}$. On the transverse cut surface, IGC is more frequent in the fine-grained surface layer. The depth of attack exceeds $500 \mu \mathrm{m}$ (Figure 8). In the peak-aged and overaged conditions, the bar's surface only exhibits pitting corrosion with a depth of about $100 \mu \mathrm{m}$. Besides that, corrosion spreads parallel to and beneath the surface, along the bands of coarse cathodic phases. The authors in ${ }^{10}$ describe this type of corrosion as ELA (Exfoliation-Like Attack). On the transverse cut surface, corrosion is of the pitting type as well. It is
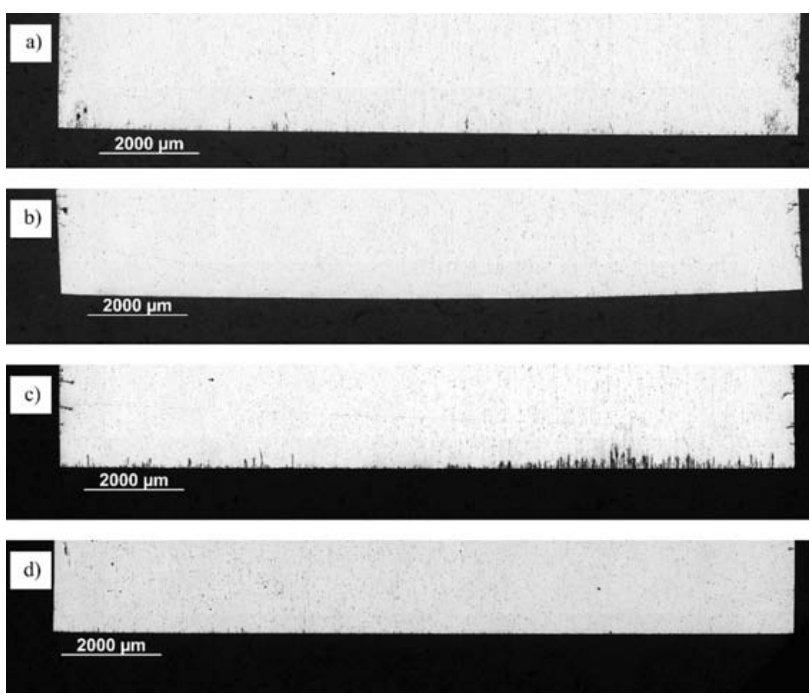

Figure 10: Corrosion on the $\mathrm{HF}$ transverse cut surface upon ageing: a) $180{ }^{\circ} \mathrm{C} / 4 \mathrm{~h}$ under-aged, b) $180{ }^{\circ} \mathrm{C} / 8 \mathrm{~h}$, c) $\left.180{ }^{\circ} \mathrm{C} / 4 \mathrm{~h}+205^{\circ} \mathrm{C} / 4 \mathrm{~h}, \mathrm{~d}\right)$ $180{ }^{\circ} \mathrm{C} / 4 \mathrm{~h}+220^{\circ} \mathrm{C} / 4 \mathrm{~h}$ overaged

Slika 10: Korozija na prečnem prerezu HF, po staranju: a) $180{ }^{\circ} \mathrm{C} / 4 \mathrm{~h}$ podstarano, b) $180{ }^{\circ} \mathrm{C} / 8 \mathrm{~h}$, c) $180{ }^{\circ} \mathrm{C} / 4 \mathrm{~h}+205^{\circ} \mathrm{C} / 4 \mathrm{~h}$, d) $180{ }^{\circ} \mathrm{C} / 4 \mathrm{~h}+$ $220{ }^{\circ} \mathrm{C} / 4 \mathrm{~h}$ prestarano much deeper and, again, more frequent in the near-surface areas.

\subsubsection{Corrosion tests of specimens of HF drawn and straightened bars}

Surface corrosion of selected specimens in variously aged conditions is illustrated in Figure 9. The corrosion of the transverse cut surface is shown in Figure 10. Results of the evaluation of corrosion are given in Table 7.

Table 7: Evaluation of corrosion and hardness of samples HF Tabela 7: Ocena korozije in trdota vzorcev HF

\begin{tabular}{|c|c|c|c|c|}
\hline $\begin{array}{c}\text { Sample } \\
\text { HV5 }\end{array}$ & US & Place & $\begin{array}{l}\text { Corrosion } \\
\text { depth }(\mu \mathrm{m})\end{array}$ & $\begin{array}{l}\text { Corrosion } \\
\text { type }\end{array}$ \\
\hline \multirow[b]{2}{*}{$\begin{array}{c}\mathrm{HF}-3 \\
123\end{array}$} & $180^{\circ} \mathrm{C} / 4 \mathrm{~h}$ & Surface & 364.9 & IGC \\
\hline & Under-ageing & $\begin{array}{c}\text { Transverse } \\
\text { cut }\end{array}$ & 545.9 & $\begin{array}{c}\text { IGC, } \\
\text { near-edge }\end{array}$ \\
\hline \multirow{2}{*}{$\begin{array}{l}\mathrm{HF}-4 \\
123.3\end{array}$} & $180^{\circ} \mathrm{C} / 8 \mathrm{~h}$ & Surface & 307.1 & Pitting \\
\hline & peak ageing & $\begin{array}{c}\text { Transverse } \\
\text { cut }\end{array}$ & 93.6 & $\begin{array}{l}\text { Pitting, } \\
\text { sporadic }\end{array}$ \\
\hline \multirow{2}{*}{$\begin{array}{c}\mathrm{HF}-3 \mathrm{~B} \\
115.4\end{array}$} & $\begin{array}{c}180{ }^{\circ} \mathrm{C} / 4 \mathrm{~h}+ \\
205^{\circ} \mathrm{C} / 4 \mathrm{~h}\end{array}$ & Surface & 348.9 & $\begin{array}{c}\text { Pitting, } \\
\text { transgranula } \\
\mathrm{r}\end{array}$ \\
\hline & Over-ageing & $\begin{array}{c}\text { Transverse } \\
\text { cut }\end{array}$ & 471.2 & Pitting \\
\hline \multirow{2}{*}{$\begin{array}{c}\mathrm{HF}-3 \mathrm{~A} \\
110.3\end{array}$} & $\begin{array}{c}180{ }^{\circ} \mathrm{C} / 4 \mathrm{~h}+ \\
220^{\circ} \mathrm{C} / 4 \mathrm{~h}\end{array}$ & Surface & 366.1 & $\begin{array}{c}\text { Pitting, } \\
\text { transgranula } \\
\mathrm{r}\end{array}$ \\
\hline & Over-ageing & $\begin{array}{c}\text { Transverse } \\
\text { cut }\end{array}$ & 122.3 & $\begin{array}{l}\text { Pitting, } \\
\text { sporadic }\end{array}$ \\
\hline
\end{tabular}

In specimens in underaged condition, there is deep IGC on the bar's surface, as well as on the transverse cut surface. In the peak-aged and over-aged conditions, the bar surface only exhibits pitting corrosion that spreads perpendicularly to the surface to a depth of more than $300 \mu \mathrm{m}$. It is transgranular corrosion, as it penetrates the grains. On the transverse cut surfaces, the least extensive corrosion was found in the peak-aged condition (Figure 10b). In the slightly-overaged condition, the corrosion is extensive and deep (Figure 10c). In increasingly overaged specimens, the number and depth of corrosion attack locations decrease (Figure 10d).

\section{DISCUSSION}

The main mechanism of IGC is reported to be the formation of micro-galvanic cells between cathodic more-noble phases and the depleted (precipitate-free) zones along the grain boundaries. In this case, the key cathodic phase is the Q-phase $\left(\mathrm{Al}_{4} \mathrm{Mg}_{8} \mathrm{Si}_{7} \mathrm{Cu}_{2}\right)$, which precipitates along the grain boundaries. As a result, the grain-boundary areas become depleted of $\mathrm{Cu}$ and other elements. In addition, a thin $\mathrm{Cu}$ film forms along the grain boundaries and plays the key role in IGC growth and propagation. ${ }^{3-6}$ The entire precipitation process is thermally activated and depends on the diffusion of alloying elements. Its rate is described by an Arrhenius equation. With increasing ageing temperature and time, 


\section{P. SLÁMA, J. NACHÁZEL: EFFECT OF THERMOMECHANICAL TREATMENT ON THE INTERGRANULAR CORROSION ...}

the Q-phase precipitates coarsen and the volume fraction of the $\mathrm{Cu}$ film along the grain boundaries decreases. Consequently, the susceptibility to IGC is reduced and the material typically exhibits only pitting corrosion.

The EN AW-6064 alloy contains a number of other primary cathodic phases $\left(\mathrm{Bi}, \mathrm{Pb}\right.$, alpha- $\mathrm{Al}_{15}(\mathrm{Fe}, \mathrm{Mn}, \mathrm{Cu}$, $\mathrm{Cr})_{3} \mathrm{Si}_{2}$ ). Their arrangement in bands with short distances between the phases helps the pitting corrosion to propagate to larger depths, most notably beneath the transverse cut surface (Figure $4 \mathbf{d}$ ). In some cases there were great differences between the corrosion attack on the bar's surface and on the transverse cut surface.

In the extruded bars (HA1), it was found that with increasing over-ageing the large-depth IGC changes into shallower pitting corrosion, which is in agreement with the findings presented in ${ }^{3-6}$. In the overaged condition, the corrosion penetrations on the transverse cut surface were smaller. Sporadic pitting corrosion with a depth of about $100 \mu \mathrm{m}$ was found.

In the drawn bars (HB2), the transition from IGC to shallower pitting corrosion was observed as well. Unlike the specimens from bars that had not been drawn, all the specimens in this group showed very deep corrosion (more than $500 \mu \mathrm{m}$ ) on their transverse cut surfaces (Figure 8).

In the drawn and straightened bars (HF), another type of corrosion was observed. In the under-aged bars, IGC was found on both the bar surface and the transverse cut surface. With ongoing ageing, IGC changes into pitting corrosion, which - on the bar surface - propagates perpendicularly to the surface and by transgranular mechanism to a larger depth than the pitting corrosion in the drawn bars (Figures 9b to 9d). This corrosion type corresponds to transgranular stress corrosion cracking (SCC). ${ }^{14}$ The difference can be attributed to the variation between the internal stresses induced by drawing and straightening. Drawing typically induces tensile stress. Straightening, however, involves alternating bending loads and tensile and compressive stresses, which lead to non-uniform residual stress that promotes corrosion propagation, perpendicularly to the surface and to a larger depth. The transverse cut surface, unlike HB2 specimens, shows - in some cases - shallow sporadic pitting corrosion (Figures $\mathbf{1 0 b}$ and 10d).

\section{CONCLUSION}

Extruded and drawn bars from the EN AW-6064A alloy were used for exploring the impact of thermomechanical treatment on intergranular corrosion (IGC). The effects of forming (drawing and straightening) and artificial ageing were mapped, along with the type of corrosion and corrosion depth on the bar surface and its transverse cross-section. The corrosion tests were carried out in accordance with EN ISO 11486 - method B.

The results of the corrosion tests show that the thermomechanical treatment affects both the type and depth of corrosion.
The bar surface exhibited three types of corrosion:

- IGC in under-aged specimens: typically extensive corrosion with a depth of more than $300 \mu \mathrm{m}$.

- Pitting corrosion in more aged and over-aged extruded/drawn bars, where the corrosion depth was approximately $100 \mu \mathrm{m}$.

- Transgranular pitting corrosion in more aged and over-aged bars that had undergone final straightening. Here, the corrosion depth was larger and exceeded $300 \mu \mathrm{m}$.

With more intensive ageing and over-ageing (temperature, time), IGC changed into pitting corrosion in extruded/drawn bars. There was an adverse impact of the post-drawing straightening operation on the resistance to surface corrosion in the bars, evidenced by deep transgranular pitting corrosion.

In most cases the transverse cross-sections exhibited very deep pitting corrosion with depths up to $800 \mu \mathrm{m}$, which followed the bands of coarse cathodic phases. Exceptions were found in severely over-aged bars (extruded or extruded and straightened), which showed sporadic pitting corrosion with depths of approximately $100 \mu \mathrm{m}$

\section{Acknowledgements}

This paper was created by project Development of West-Bohemian Centre of Materials and Metallurgy No.: LO1412, financed by the MEYS of the Czech Republic.

\section{REFERENCES}

${ }^{1}$ D. G. Altenpohl, Aluminum: Technology, Applications, and Environment: A Profile of a Modern Metal, 6th ed., Minerals, Metals, and Materials Society, Warrendale, Pennsylvania 1998

2 J. E. Hatch (Ed.), Aluminium - Properties and Physical Metallurgy, ASM, Ohio 1984

${ }^{3}$ G. Svenningsen, J. E. Lein, A. Bjorgum, J. H. Nordlien, Y. D. Yu, K. Nisancioglu, Effect of low copper content and heat treatment on intergranular corrosion of model AlMgSi alloys, Corrosion Science, 48 (2006) 1, 226-242, doi:10.1016/j.corsci.2004.11.025

${ }^{4}$ G. Svenningsen, M. H. Larsen, J. H. Nordlien, K. Nisancioglu, Effect of high temperature heat treatment on intergranular corrosion of $\mathrm{AlMgSi}(\mathrm{Cu})$ model alloy, Corrosion Science, 48 (2006) 1, 258-272, doi:10.1016/j.corsci.2004.12.003

${ }^{5}$ G. Svenningsen, M. H. Larsen, J. C. Walmsley, J. H. Nordlien, K. Nisancioglu, Effect of artificial aging on intergranular corrosion of extruded $\mathrm{AlMgSi}$ alloy with small $\mathrm{Cu}$ content, Corrosion Science, 48 (2006) 6, 1528-1543, doi:10.1016/j.corsci.2005.05.045

${ }^{6}$ M. H. Larsen, J. C.Walmsley, O. Lunder, R. H. Mathiesen, K. Nisancioglu, Intergranular Corrosion of Copper-Containing AA6xxx AlMgSi Aluminum, J. Electrochem. Soc., 155 (2008) 11, C550-C556, doi:10.1149/1.2976774

${ }^{7}$ T. Kovalčík, J. Stoulil, P. Sláma, D. Vojtěch, The Influence of Heat Treatment on Mechanical and Corrosion Properties of Wrought Aluminium Alloys 2024 and 6064, Manufacturing Technology, 15 (2015) 1, 54-61

${ }^{8}$ V. Guillaumin, G. Mankowski, Influence of Overaging Treatment on Localized Corrosion of Al 6056, Corrosion, 56 (2000), 12-23, doi:10.5006/1.3280517 


\section{P. SLÁMA, J. NACHÁZEL: EFFECT OF THERMOMECHANICAL TREATMENT ON THE INTERGRANULAR CORROSION ...}

${ }^{9}$ C. Gallais, A. Denquin, Y. Brechet, G. Lapasset, Precipitation microstructures in an AA6056 aluminium alloy after friction stir welding: Characterisation and modelling, Mater. Sci. Eng. A, 496 (2008), 77-89, doi:10.1016/j.msea.2008.06.033

${ }^{10}$ F. Eckermann, T. Suter, P. J. Uggowitzer, A. Afseth, P. Schmutz, Investigation of the exfoliation-like attack mechanism in relation to $\mathrm{Al}-\mathrm{Mg}-\mathrm{Si}$ alloy microstructure, Corrosion Science, 50 (2008) 7, 2085-2093, doi:10.1016/j.corsci.2008.04.003

${ }^{11}$ Z. Wang, H. Li, F. Miao, W. Sun, B. Fang, R. Song, Z. Zheng, Improving the intergranular corrosion resistance of $\mathrm{Al}-\mathrm{Mg}-\mathrm{Si}-\mathrm{Cu}$ alloys without strength loss by a two-step aging treatment, Mater. Sci. Eng. A, 590 (2014), 267-273, doi:10.1016/j.msea.2013.10.001
${ }^{12}$ A. Halap, M. Popović, T. Radetić, V. Vaščić, E. Romhanji, Influence of the thermo-mechanical treatment on the exfoliation and pitting corrosion of an AA5083-type alloy, Mater. Tehnol., 48 (2014) 4, 479-483

${ }^{13}$ EN ISO 11846, Corrosion of metals and alloys, Determination of resistance to intergranular corrosion of solution heat- treatable aluminium alloys

${ }^{14}$ ASM Handbook, Vol. 13, Corrosion, ASM, Ohio 1987 